\title{
Complete validation of plumbline distances as a screening tool for sagittal plane deformities
}

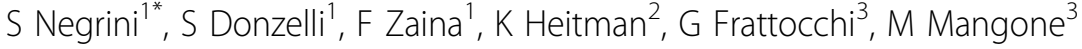 \\ From 8th International Conference on Conservative Management of Spinal Deformities and SOSORT 2011 \\ Annual Meeting \\ Barcelona, Spain. 19-21 May 2011
}

\section{Background}

While for scoliosis screening Scoliometer has been widely validated, there is no validated screening instrument for sagittal plane deformities.

\section{Purpose}

To validate a screening tool for sagittal plane deformities (plumbline distances - PD).

\section{Material and methods}

Surface measurements (Formetric) of kyphosis/lordosis were considered the Gold Standard [1]. Correlations between Human PD (HPD), Formetric PD (FPD) and Gold Standard were searched in 129 school screening pupils (age 11.8 \pm 0.7 ): not correlated PD were eliminated. ROC-curve statistical technique was used to determine the best cut-off for remaining PDs.

Final FPD were verified in 7257 Formetric evaluations from the Diers database (3 age groups: 6-9y12m, 10$17 \mathrm{y} 12 \mathrm{~m}, 18-78)$. Final HPD were verified in 103 scoliosis/ hyperkyphosis patients aged $14.3 \pm 2.2$.

\section{Results}

HPDs correlate with FPDs (0.49-0.57), C7+L3 with kyphosis (0.54-0.58), L3 with kyphosis and lordosis (0.420.56). To identify $60^{\circ}$ kyphosis, a cut-off of $90 \mathrm{~mm}$ for $\mathrm{C} 7+\mathrm{L} 3$ demonstrated an overall accuracy range of 75-93\%, high specificity (78-95\%), variable sensitivity (25-83\%). HPDs very well ruled out normals (negative predictive value -PV 93-99\%), even if with high numbers of false positives (positive predictive value +PV 8-25\%). Similarly, for $55^{\circ}$ lordosis, a cut-off of $45 \mathrm{~mm}$ for L3 demonstrated a $75-94 \%$ overall accuracy, $70-94 \%$

${ }^{1}$ ISICO (Italian Scientific Spine Institutes) Milan, Italy

Full list of author information is available at the end of the article specificity and $25-100 \%$ sensitivity, with -PV $93-100 \%$ and +PV 9-20\%.

\section{Conclusions}

In all groups evaluated results were similar. Below $90 \mathrm{~mm}$ C7+L3 (45mm L3) almost all pupils are below $60^{\circ}$ kyphosis ( $55^{\circ}$ lordosis); in the remaining $20 \%$ a not-ionizing surface evaluation (Formetric) should be proposed to identify real deformities (1 out of 4 to 10).

\section{Author details}

${ }^{1}$ ISICO (Italian Scientific Spine Institutes) Milan, Italy. ${ }^{2}$ Diers International, GMBH, Germany. ${ }^{3}$ Cattedra Medicina Fisica e Riabilitativa, Università La Sapienza, Roma, Italy.

Published: 27 January 2012

\section{Reference}

1. Weiss HR, Dieckmann J, Gerner HJ: Outcome of the in-patient rehabilitation in patients with $\mathrm{M}$. Scheuermann evaluated by surface topography. Stud Heelth Technol Inform 2002, 88:246-9.

doi:10.1186/1748-7161-7-S1-016

Cite this article as: Negrini et al:: Complete validation of plumbline distances as a screening tool for sagittal plane deformities. Scoliosis 2012 7(Suppl 1):016

Submit your next manuscript to BioMed Central and take full advantage of:

- Convenient online submission

- Thorough peer review

- No space constraints or color figure charges

- Immediate publication on acceptance

- Inclusion in PubMed, CAS, Scopus and Google Scholar

- Research which is freely available for redistribution

\section{() Biomed Central}

(c) 2012 Negrini et al; licensee BioMed Central Ltd. This is an open access article distributed under the terms of the Creative Commons Attribution License (http://creativecommons.org/licenses/by/2.0), which permits unrestricted use, distribution, and reproduction in any medium, provided the original work is properly cited. 